\title{
ADORA3 wt Allele
}

National Cancer Institute

\section{Source}

National Cancer Institute. ADORA3 wt Allele. NCI Thesaurus. Code C51399.

Human ADORA3 wild-type allele is located in the vicinity of 1 p13.2 and is approximately 81 $\mathrm{kb}$ in length. This allele, which encodes adenosine A3 receptor protein, is involved in the prevention of ischemic injury to cardiac ventricular cells and may play a role in reproduction. 